\title{
Synectic HOTS Oriented: Development of Teaching Materials for High School Physics Learning
}

\author{
Eko Setyadi Kurniawan*, Mundilarto, Edi Istiyono \\ Postgraduate Program, Yogyakarta State University, Indonesia \\ Received August 2, 2020; Revised September 7, 2020; Accepted October 19, 2020
}

\section{Cite This Paper in the following Citation Styles}

(a): [1] Eko Setyadi Kurniawan, Mundilarto, Edi Istiyono, "Synectic HOTS Oriented: Development of Teaching Materials for High School Physics Learning," Universal Journal of Educational Research, Vol. 8, No. 11, pp. 5547 - 5554 , 2020. DOI: 10.13189/ujer.2020.081158.

(b): Eko Setyadi Kurniawan, Mundilarto, Edi Istiyono (2020). Synectic HOTS Oriented: Development of Teaching Materials for High School Physics Learning. Universal Journal of Educational Research, 8(11), 5547 - 5554. DOI: 10.13189/ujer.2020.081158.

Copyright $\bigcirc 2020$ by authors, all rights reserved. Authors agree that this article remains permanently open access under the terms of the Creative Commons Attribution License 4.0 International License

\begin{abstract}
Most of physics learning materials in senior high school have not met the HOTS aspects. One of the HOTS aspects is creative thinking, which is also found in Synectic learning model. Both Synectic and HOTS have not much found in learning process or physics teaching materials. Even though, the physics learning process needs the creative thinking. This study aimed to develop the teaching materials based on Synectic and HOTS. ADDIE model was used in this study. The teaching materials which were developed in this study were lesson plan, student physics module, and also learning outcome test with HOTS aspect. Data analysis used descriptive analysis which described the validity level, practical and also effectiveness of the teaching materials. The results showed that learning materials met the valid criteria, the average score was 3.45 , practicality was $84.77 \%$ and the effectiveness of physics learning was $92 \%$. HOTS aspect $91.67 \%$ and $85.94 \%$ in the comfortable category and the pre-test and post-test results have a score of 0.389 in the moderate category. In conclusion, Synectic HOTS oriented teaching materials are important to be applied in physics learning so that students' higher order thinking skills was improved. Besides, the learning outcome was also increased. Thus, this learning materials need to be developed for the large scale students.
\end{abstract}

Keywords Physics Teaching Materials, Synectic, HOTS

\section{Introduction}

$21^{\text {st }}$ century learning aims to grow students both spiritually and emotionally. It means that the learning should be students-centered so that they can increase so many skills [1], [2]. One of the skills that should be grown is creative thinking. Creative thinking is very needed in all subjects include physics. A creative thinking skill in physic is important to find the solution in learning's problem. PISA reported that students in Indonesia have poor science literation OECD in 2016. It is caused by lack of understanding in complex information, lack of understanding in concept, physical analysis and problem solving, lack of understanding in using equipment and procedure also doing investigation. It is in line with the average score of national exam in 2019 for all subjects are below 70 .

The average score of physics, nationally, is 46.35 . It can be categorized as low. It increases but not that significant. The score is below 50. It can be concluded that the students' cognitive skills need to be increased. One of the ways in increasing the score is through learning strategies.

One of the strategies used by government is the implementation of higher order thinking skill based on Permendiknas number 21 about content standard, number 22 about process standard, and number 23 about assessment standard.

A revised Bloom's Taxonomy stated that the ability to think at a higher level includes cognitive skills in analyzing, evaluating, and creating [3], [4]. Students' thinking skill 
can affect learning effectiveness so that if they trained well, it gives positive effect to their knowledge [5]. Analyzing (C4) and evaluating (C5) are the important part in HOTS. Analysis is the process in dividing lesson material into part to find the relation of each part [6]. Analysis categorization includes: (1) differentiation, decide the critical information, (2) Organization, rearrange the information and (3) attributing, decide the aims of the data [2]. Evaluating skill is a process of decision-making based on the specific criteria namely examining and criticizing. HOTS should be used in school so that students get the better cognitive skills [7], [8].

Education is about two-way communication between students and teachers to achieve learning's objective [9]. Learning can be classical, online and also both of them [10]. Learning strategies give contribution to the learning process [8], [11]. There are some learning strategies namely implementation of HOTS, the using of technology, and learning based project. These can be applied by using some methods, models, media, and also learning materials to solve students' problem [12], [13]. Thus, teachers need to build learning materials based on students' need. The practical learning process is characterized by understanding and achieving the competencies that students achieve as learning objectives [14]. It leads to the students' learning outcomes [10], [11]. Through those learning materials students can build better knowledge so that learning materials should meet valid, practical and also effective criteria [15].

A professional teacher takes an important role in creating successful students. Teachers should give the best facilities to the students so that they can get the best result. Teachers can use HOTS in the learning process. [16]. Some senior high schools in Purworejo have implemented learning process based on HOTS however they face some obstacles. Teachers stated that students face difficulties in understanding concept and analysis in physics. That was gotten from the interview and also observation. Besides, students are passive in learning process so that the learning process is teacher-centered.

Synectic is closely related to the creativity and metacognitive [17], [18]. William Gordon (1961) developed model based on creativity like metaphor, direct analogy and intense personal conflict [19], [20]. The main focus of synectic model is increasing creativity which is closely related to the HOTS concept (analysis, evaluate, and creation) [21]. However, teachers only use available teaching materials like textbook and students' worksheet. They have not constructed their own teaching materials because they do not understand the concept. Besides, they do not have time to do it. 25 from 32 students do not understand about learning based HOTS so that they cannot answer the test. Students' thinking skills can be categorized as poor then their score is 70 . Thus, there should be physics learning materials which are oriented in synectic HOTS to measure students' enhancement in analyzing and evaluating. Learning materials should meet valid, practical and effective criteria.

\section{Research Methods}

This was a research and development study, adapt the ADDIE (Analysis, Design, Development, Implementation, and Evaluation) [22]. The stages of developing Synectic HOTS-oriented Physics teaching materials are presented in Figure 1.

\subsection{Analysis Stage}

The analysis phase aimed to determine the conditions of learning include: (1) curriculum analysis, (2) needs analysis both for students and teacher toward learning materials, (3) concept and content analysis, (4) assignments analysis, and (5) formulation of learning objectives specifications. These steps were used as the foundation in preparing Synectic HOTS-oriented of Physics teaching material.

\subsection{Design Stage}

The design stage was designing teaching material products which includes planning and learning strategies based on the previous needs analysis stages. Components of planning student teaching materials: 1) title, 2) introduction, 3) description that contains basic competencies, indicators, and learning objectives that refer to the 2013 curriculum revision, 4) number of chapters and sub chapters, 5) practice and evaluation, 6) reference. The second point was to determine the method of presenting the learning using teaching materials in the form of tutorials and classical learning methods.

\subsection{Development Stage}

The stages of development included developing learning content in the form of HOTS-oriented Physics teaching materials. The early stage was made a prototype which tested by expert to get both valid and reliable product.

\subsection{Implementation Stage}

This stage implemented learning materials to the students. The feasibility test for learning physics using teaching materials, practicality tests in the use of teaching materials, and the effectiveness of learning were found here. 


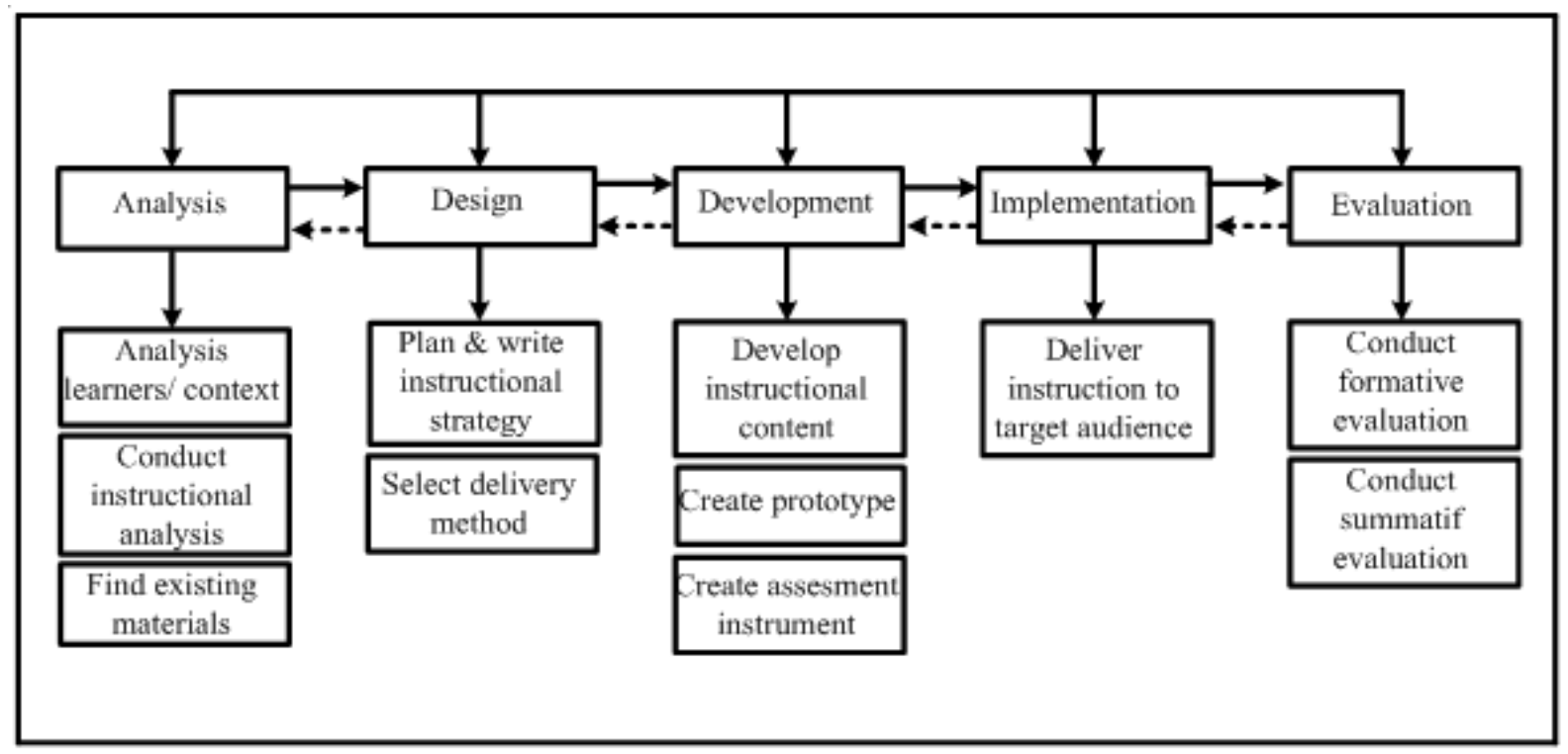

Figure 1. The developing stages of Synectic HOTS-Oriented Learning Materials

Validity, practicality, and effectiveness of learning materials have been found by using descriptive analysis. There were 32 students of SMA N 6 Purworejo class X for Impuls and momentum material. Developmental stages were developed learning materials namely lesson plan and also modules based on synectic HOTS-oriented. The next stage was feasibility test to measure validity, reliability and effectiveness of learning material.

The instrument used to determine the validity and effectiveness was validation sheet and test. To determine both analysis and evaluative ability used learning outcomes test which was HOTS oriented developed by [23]. The questionnaire was used to find students' response to the learning materials.

Learning materials, oriented to synectic HOTS, was validated by seven experts namely physics expert, media and learning materials expert, and also physic teachers. They should give score between 1 to 5 with considering format, language, content (4) and synectic HOTS. A validity criterion is in Table 1 .

Table 1. Validity Criteria

\begin{tabular}{|c|c|c|}
\hline No & $\boldsymbol{V a}$ Average Value & Validity criteria \\
\hline 1 & $3,6 \leq V a \leq 4,0$ & very valid \\
\hline 2 & $2,6 \leq V a \leq 3,5$ & valid \\
\hline 3 & $1,6 \leq V a \leq 2,5$ & quite valid \\
\hline 4 & $V a \leq 1,5$ & invalid \\
\hline
\end{tabular}

Percentage Agreement (PA) done by some experts, equation (1), was used to estimate the reliability. Instrument was categorized as reliable if the $\mathrm{PA}>75 \%$.

$$
P A=\left(1-\frac{A-B}{A+B}\right) \times 100 \%
$$

Practicality test was given to the students and teachers through questionnaire include 1) the ease in using teaching materials, 2) the learning time, 3) students' interest in learning with teaching materials, 4) available interpretation, 5) unambiguous. The criteria of practicality are very practical, practical, less impractical, and impractical. While the effectiveness of teaching material products includes 1) $85 \%$ of 32 students complete learning with a minimum value $(\mathrm{KKM})$ of 70,2$)$ positive student responses to teaching materials, 2) student learning achievement does not exceed classical learning time, and 3) the determined product meets the criteria of good validity. Student learning outcomes are known through the pretest and posttest learning achievement tests.

The effectiveness of teaching materials in this case: 1) student learning outcomes with a Synectic-HOTS aspect of at least $85 \%$;2) student achievement at least $75 \%$; 3) students' positive response to learning is at least $85 \%$; 4) and the learning time does not exceed the classical teaching time [24]. The increase in student achievement in higher order thinking skills was determined using the N-Gain formula from Hake [25], which is shown in Equation 2.

$$
N-\text { gain }=\frac{\text { posttest }- \text { pretest }}{\text { ideal score }- \text { pretest }}
$$

The criteria for gain normalized as following Table 2.

Table 2. Criteria for N-Gain

\begin{tabular}{|c|c|}
\hline Gain score & Interpretation \\
\hline $\mathrm{g}>0.7$ & Hight \\
\hline $0.3<\mathrm{g}<0.7$ & Medium \\
\hline $\mathrm{g}<0.3$ & Low \\
\hline
\end{tabular}




\section{Result}

\subsection{Analysis Phase}

At this stage an analysis was carried out to determine the physics learning process in the class of SMA Negeri 6 Purworejo. Based on observations, physics learning outcomes are not optimal even though the teacher has applied various learning methods to improve students' understanding of physics concepts and analysis. Some students have difficulty developing analytical skills and the ability to evaluate both the concept and analysis of Impulse and Momentum material. Teachers and students had difficulty presenting physics learning based on Synectic HOTS. Teaching materials used so far are text books and student worksheets $(L K S)$ that have not emphasized aspects of analysis and evaluation skills.

Task analysis was carried out to determine the stages of completing tasks carried out by students during learning which refers to concept analysis, in addition to details of task analysis for Work and Energy and Impulse and Momentum materials, which are related to competencies and learning achievement indicators. The formulation of learning objectives is a reference in designing teaching materials based on the metacognition approach and in preparing tests.

\subsection{Design Stage}

The purpose of the design phase was to design draft HOTS-oriented physics teaching materials products. The stages of learning planning is contained in the lesson plan $(R P P)$ for two times to the session. Teaching materials for students was based on HOTS-oriented physics modules, learning achievement test sheets, product evaluation instrument design, and learning activity questionnaire. All products at this stage are presented in draft 1 .

\subsection{Development Stage}

At this stage, the validation of product was carried out by physicists, media experts, and physics teachers on the aspects of content validity, namely element format, language, content, and HOTS as in Table 3.

Table 3. Validity of teaching materials

\begin{tabular}{|c|c|c|}
\hline Content Aspect & Score & Criteria Validity \\
\hline Formatting & 3,50 & Valid \\
\hline Content & 3,40 & Valid \\
\hline Language and Readability & 3,55 & Very valid \\
\hline HOTS aspect & 3,35 & Valid \\
\hline Average & 3,45 & Valid \\
\hline
\end{tabular}

Table 2 showed the instrument validity, obtained an average score of 3.45 for expert validation, categorized as valid. Lesson plan 3.35; the student module gets a score of 3.53; the reliability of teaching materials was estimated by using a Percentage Agreement (PA), where PA $\geq 75 \%$. The results of the reliability analysis of teaching materials, the product obtained an average score percentage agreement for each aspect was $86.5 \%$ so that the teaching materials were categorized as reliable.

\subsection{Implementation Stages}

At this stage, the implementation, practicality, and effectiveness of physics learning were tested using teaching materials in SMA N 6 Purworejo on the physics material of Momentum and Impulses.

\subsection{Learning performance test results}

The results of the implementation test were carried out once with a pre-test and post-test. The instrument used was HOTS-based physics problems, the subject of Momentum and Impulse, which amounted to 10 questions. The questions for the pre-test and post-test are different but have the same weight, the results of the implementation of learning is presented in Figure 2. 


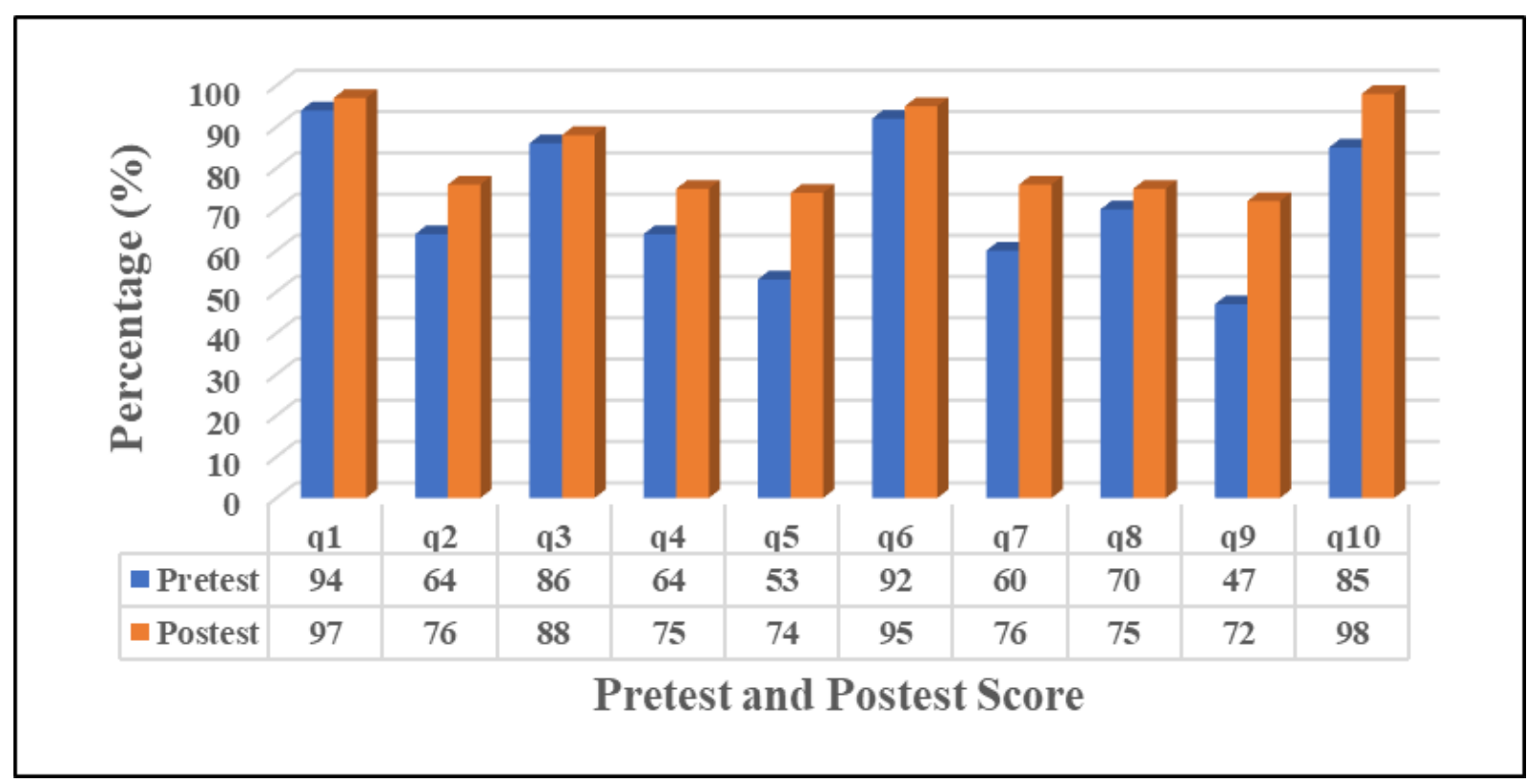

Figure 2. Learning Test Results

The results of learning feasibility test on Figure 2, 30 of 32 student or $92 \%$ have been completed. The results of the student's ability test during the pre-test and post-test have been improved, although item number 5 and number 9 below the criteria. The $\mathrm{N}$-gain score was 0.3894 categorized as medium category. There are indicates that the HOTS question material is not fully understood by students well, so it needs to be improved and emphasized the HOTS aspects of teaching materials delivered by the Physics teacher in the class.

\subsection{Practicality Test of Teaching Material}

The results of practicality test in teaching materials were obtained from the results of the feasibility study questionnaire by the teacher and students, presented in Figure 3. The aspects of the ease of use of teaching materials showed efficient and practical criteria of $91.67 \%$ and $88.28 \%$. The time aspect shows that the practical criteria are $83.33 \%$ and $85.16 \%$ effective, this shows that the learning process using teaching materials does not exceed the time limit of the classical learning process, and teachers do not need more time to explain the learning material. Aspects of student interest in using teaching materials in practice criteria are $83.33 \%$ and $80, .47 \%$ which indicate an interest in independent learning, in other words the teacher acts as a facilitator. Students' interest in teaching materials is categorized as quite practical; this is indicated by the percentage acquisition of $75 \%$ and $82.81 \%$. Students get a practical category but need to improve their analytical skills in physics problem solving in the aspect of ease in interpreting the conceptual formulation and physical analysis of HOTS-based problem solving, including the fairly practical category, namely $83.33 \%$ and $80.47 \%$. There are indications that teaching materials can help interpret concepts and analyzes facilitated by the teacher. The HOTS aspect of teaching materials is included in the comfortable category, namely $91.67 \%$ and $85.94 \%$ which indicate that the teaching material contains HOTS elements in the form of concepts, analyzes, and questions. The results are shown in Figure 3. 


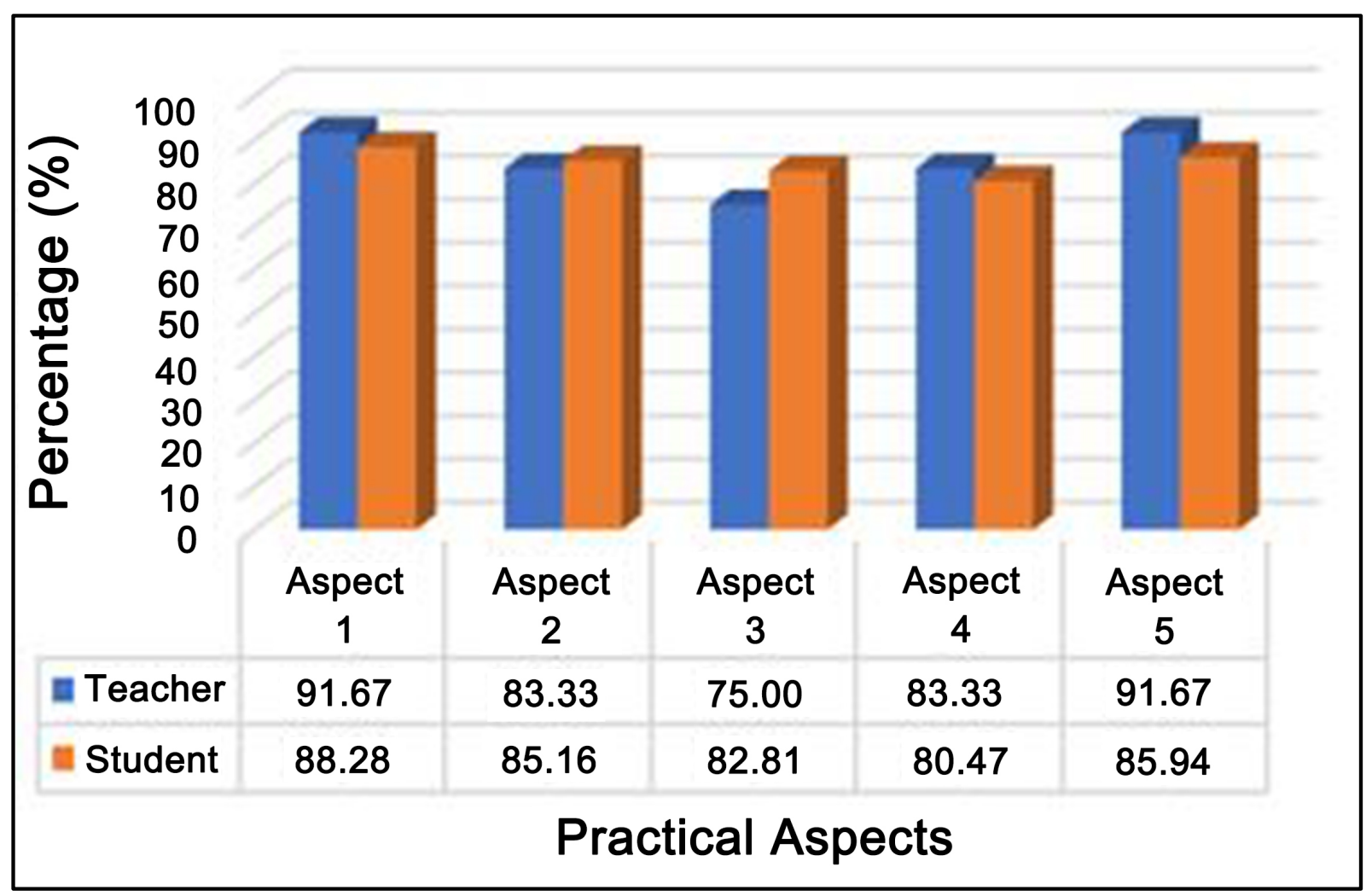

Figure 3. Practical Test Result of Teaching Materials by Teacher and Student

\subsection{Teaching Material Effectiveness Test}

A validated teaching material then applied in physics learning that their effectiveness can be determined. The data obtained, percentage of physics learning application using teaching materials, includes preliminary activities, core activities, and closing by $92 \%$, categorized as met the minimum criteria. $80 \%$ of students give positive responses to teaching materials. The result of calculating pre-test and pos-test with $\mathrm{N}$-gain a score of 0.3894 in the medium category, the allocation of time for the learning process using teaching materials that are developed do not exceed classical learning.

\subsection{Evaluation Stage}

The last stage in the series of process of developing Synectic HOTS-oriented physics teaching materials is the evaluation stage. Based on the results of the application, the Synectic HOTS-oriented physics teaching material is suitable for use in learning physics.

\section{Discussion}

Based on the data analysis, it is known that the developmental teaching materials are in the practical category and meet the effective criteria, although in the moderate category. This is in line with [26] research on the development of student worksheet mastery based on genetics learning. Likewise [8] who conducted a higher order thinking needs analysis in learning. This is in line with the study of the development of media and teaching materials, among others [27] which has developed a learning model to improve job skills. At the same time, [28] also developed PISA-based student worksheets to improve students' problem skills. The development of teaching materials to improve students' hand-on ability was also carried out by [29] in his study, which stated that there is a relationship between the hand-on model against students who indulge in the law of energy conservation.

In this study, the teaching materials developed were in the form of a physics module which was oriented towards Synectic HOTS which included aspects of the ability to analyze and evaluate. Some are adapted to local characteristics and wisdom so that they help solve physical problems in everyday life for more meaningful learning. This is in line with Ausubel's learning theory [30] which states the importance of meaningful learning by linking new information and the concept of learning material.

The aspects of HOTS can be trained through a learning process that emphasizes elements of analyzing, evaluating, and being creative in teaching materials and evaluation instruments as reviewed by [23]. Through Synectic HOTS, students are trained to do problem analysis based on understanding concepts and experiences in everyday life to gain new understanding and then prove the truth through their ability to evaluate [31], [32]. Regarding this [33], [34], who analyzed higher order thinking skills in solving HOTS 
problems, the results are in line with research [35]. Through this ability, students' ideas for solving problems in the form of creativity were written by [36], who suggested that creativity could reflect flexibility, originality of thought, and the ability to process new ideas.

The implementation of learning by using teaching materials has achieved the above score of minimum completeness criteria of $92 \%$. However, learning outcomes (pre-test or post-test) related to HOTS elements reported that some items need to be improved. This is because the teaching materials that are oriented towards Synectic HOTS are developed in addition to focusing on the cognitive aspects in it, they also relate to the contextual problems of physics in everyday life. Based on the experiences in this environment, students' concepts and imaginations related to the idea of learning physics arise, making it easier for students to solve problems by making analyzes and evaluations of these problems.

Practicality and effectiveness test of teaching materials can be categorized as practical and effective. The learning process was limited into two meetings, 6 x 45 minutes. Based on the mean percentage of pre-test and post-test data, students' responses to the teaching materials developed were positive, namely $87.30 \%$. This means that students were helped by implementing teaching materials to carry out analysis and evaluation activities in Impulse and Momentum subjects. Some have shown that teaching materials are useful in terms of student responses, which is supported by research [28] on students' positive responses to learning using teaching materials. The same thing was expressed by [7], [37] that the teaching materials developed were useful in terms of validity, practicality, and increased understanding of concepts. This is supported by [38] related to the development and application of a curriculum model in the learning process to develop higher order thinking skills in schools.

\section{Conclusions}

It can be concluded that Synectic HOTS Physics-oriented teaching materials met valid, practical, useful criteria. Students' ability both analyzing and evaluating has increased in the moderate criteria so that the learning materials can be used in physics class which based on HOTS Synectic. The lack of this study is topic of the lesson. For further research there should be a researcher who develop another learning materials based on synectic HOTS.

\section{Acknowledgments}

This research was supported by the Ministry of Finance of the Republic of Indonesia through the Education Fund Management Institute (LPDP) with a contract number:
PRJ-29 / LPDP.3 / 2018.

\section{REFERENCES}

[1] A. M. Al Kandari and M. M. Al Qattan, "E-Task-Based Learning Approach to Enhancing 21st-Century Learning Outcomes.," Int. J. Instr., vol. 13, no. 1, pp. 551-566, 2020.

[2] P. H. Tyan, F. A. Rahman, and M. S. Sarvestani, “Teachers' Readiness in Implementing and Facilitating $21^{\text {st }}$ Century Learning," Univers. J. Educ. Res., vol. 8, no. 1A, pp. 24-29, Jan. 2020, doi: 10.13189/ujer.2020.081304.

[3] D. R. Krathwohl, "A revision of Bloom's taxonomy: An overview," Theory Pract., vol. 41, no. 4, pp. 212-218, 2002.

[4] S. M. Brookhart, "Educational assessment knowledge and skills for teachers," Educ. Meas. Issues Pract., vol. 30, no. 1, pp. 3-12, 2011.

[5] Y. M. Heong, J. M. Yunos, W. Othman, R. Hassan, T. T. Kiong, and M. M. Mohamad, "The needs analysis of learning higher order thinking skills for generating ideas," Procedia-Soc. Behav. Sci., vol. 59, pp. 197-203, 2012.

[6] Y. M. Heong, W. B. Othman, J. B. M. Yunos, T. T. Kiong, R. B. Hassan, and M. M. B. Mohamad, "The level of marzano higher order thinking skills among technical education students," Int. J. Soc. Sci. Humanity, vol. 1, no. 2, p. 121, 2011.

[7] M. N. Hassan, R. Mustapha, N. N. Yusuff, and R. Mansor, "Development of Higher Order Thinking Skills Module in Science Primary School: Needs Analysis," Int. J. Acad. Res. Bus. Soc. Sci., vol. 7, no. 2, pp. 624-628, 2017.

[8] R. S. Budiarti, Dr. Harlis, and D. Natalia, "High Order Thinking Skills for Biology Education: Applied Microbiology Learning Videos Based on Jambi Local Wisdom," Univers. J. Educ. Res., vol. 8, no. 2, pp. 689-694, Feb. 2020, doi: 10.13189/ujer.2020.080242.

[9] N. Fazriyah, Y. Supriyati, and W. Rahayu, "The Effect of Integrated Learning Model and Critical Thinking Skill of Science Learning Outcomes," J. Phys. Conf. Ser., vol. 812, p. 012014, Feb. 2017, doi: 10.1088/1742-6596/812/1/012014.

[10] S. Masino and M. Niño-Zarazúa, "What works to improve the quality of student learning in developing countries?," Int. J. Educ. Dev., vol. 48, pp. 53-65, May 2016, doi: 10.1016/j.ijedudev.2015.11.012.

[11] A. Kudryashova, T. Gorbatova, S. Rybushkina, and E. Ivanova, "Teacher's Roles to Facilitate Active Learning," Mediterr. J. Soc. Sci., Dec. 2015, doi: 10.5901/mjss.2016.v7n1p460.

[12] B. M. Jack and H. Lin, "Making learning interesting and its application to the science classroom," Stud. Sci. Educ., vol. 53, no. 2, pp. 137-164, Jul. 2017, doi: 10.1080/03057267.2017.1305543.

[13] E. Apino and H. Retnawati, "Developing Instructional Design to Improve Mathematical Higher Order Thinking Skills of Students," J. Phys. Conf. Ser., vol. 812, p. 012100, Feb. 2017, doi: 10.1088/1742-6596/812/1/012100.

[14] B. Filiz and M. Durnali, "The Views of Pre-Service Teachers 
at an Internship High School on Pedagogical Formation Program in Turkey.," Eur. J. Educ. Res., vol. 8, no. 2, pp. 395-407, 2019.

[15] J. van den Akker, R. M. Branch, K. Gustafson, N. Nieveen, and T. Plomp, Design approaches and tools in education and training. Springer Publishing Company, Incorporated, 2012.

[16] E. Istiyono, W. S. B. Dwandaru, and R. Faizah, "Mapping of physics problem-solving skills of senior high school students using PhysProSS-CAT," REiD Res. Eval. Educ., vol. 4, no. 2, pp. 144-154, 2018.

[17] Suratno et al., "The Effect of Using Synectics Model on Creative Thinking and Metacognition Skills of Junior High School Students," Int. J. Instr., vol. 12, no. 3, pp. 133-150, Jul. 2019, doi: 10.29333/iji.2019.1239a.

[18] A. D. Corebima, H. Susilo, and S. Zubaidah, "The Contribution of Metacognitive Skills and Creative Thinking Skills in 21st Century Learning," Univers. J. Educ. Res., p. 6, 2020 .

[19] A. Yousefi, "The Effects of Synectics Teaching Model in Fostering Creativity," vol. 3, no. 7, p. 7.

[20] B. Joyce, M. Weil, and E. Calhoun, "Models of teaching," 2003.

[21] D. R. Krathwohl, “A Revision of Bloom's Taxonomy: An Overview," Theory Pract., vol. 41, no. 4, pp. 212-218, Nov. 2002, doi: 10.1207/s15430421tip4104_2.

[22] M. Molenda, "In search of the elusive ADDIE model," Perform. Improv., vol. 42, no. 5, pp. 34-37, 2003.

[23] S. Ahmad, R. C. I. Prahmana, A. K. Kenedi, Y. Helsa, Y. Arianil, and M. Zainil, "The instruments of higher order thinking skills," J. Phys. Conf. Ser., vol. 943, p. 012053, Dec. 2017, doi: 10.1088/1742-6596/943/1/012053.

[24] E. Frine Tamba, S. Syafari, P. Siagian, and M. Laurence Sihotang, "Development of Realistic Mathematics Education-Based Learning Devices to Improve Mathematical Problem Solving Skills of SMP Negeri 1 Medan Students," Am. J. Educ. Res., vol. 7, no. 1, pp. 1-5, Jan. 2019, doi: 10.12691/education-7-1-1.

[25] R. R. Hake, "Interactive-engagement versus traditional methods: A six-thousand-student survey of mechanics test data for introductory physics courses," Am. J. Phys., vol. 66, no. 1, pp. 64-74, 1998.

[26] M. Yasin et al., "The guided inquiry to improve students mathematical critical thinking skills using student's worksheet," J. Educ. Gift. Young Sci., vol. 7, no. 4, pp. 1345-1360, 2019.
[27] S. Hartanto, Z. Arifin, S. L. Ratnasari, R. E. Wulansari, and A. Huda, "Developing Lean Manufacturing Based Learning Model to Improve Work Skills of Vocational Students," Univers. J. Educ. Res., vol. 8, no. 3A, pp. 60-64, Mar. 2020, doi: 10.13189/ujer.2020.081408.

[28] I. Kurniati, I. Dewi, and H. Hasratuddin, "The Development of Student Worksheet Based on PISA to Improve Problem Solving Ability," Am. J. Educ. Res., vol. 6, no. 11, pp. 15811585, Dec. 2018, doi: 10.12691/education-6-11-18.

[29] D. Wangdi, P. Kanthang, and M. Precharattana, "Development of a hands-on model embedded with guided inquiry laboratory to enhance students' understanding of law of mechanical energy conservation," vol. 18 , no. 2 , p. 27 , 2017.

[30] J. B. da Silva, "David Ausubel's Theory of Meaningful Learning: an analysis of the necessary conditions," Res. Soc. Dev., vol. 9, no. 4, p. 09932803, 2020.

[31] E. R. Seligmann, "Reaching Students Through Synectics: A Creative Solution," p. 19.

[32] C. J. Fong, Y. Kim, C. W. Davis, T. Hoang, and Y. W. Kim, "A meta-analysis on critical thinking and community college student achievement," Think. Ski. Creat., vol. 26, pp. 71-83, Dec. 2017, doi: 10.1016/j.tsc.2017.06.002.

[33] S. R. Yuliati and I. Lestari, "Higher-Order Thinking Skills (Hots) Analysis Of Students In Solving Hots Question In Higher Education," Perspekt. Ilmu Pendidik., vol. 32, no. 2, pp. 181-188, Oct. 2018, doi: 10.21009/PIP.322.10.

[34] G. Zamani and R. Rezvani, "'HOTS' in Iran's Official Textbooks: Implications for Material Design and Student Learning," p. 14, 2015.

[35] N. B. Bakar, "The Process of Thinking among Junior High School Students in Solving HOTS Question," vol. 4, no. 3, p. 8, 2015.

[36] A. Gajda, R. A. Beghetto, and M. Karwowski, "Exploring creative learning in the classroom: A multi-method approach," Think. Ski. Creat., vol. 24, pp. 250-267, Jun. 2017, doi: 10.1016/j.tsc.2017.04.002.

[37] A. Lestari, A. Saepulrohman, and G. Hamdu, "Pengembangan Soal Tes Berbasis Hots Pada Model Pembelajaran Latihan Penelitian Di Sekolah Dasar," p. 10, 2016.

[38] H. E. Vidergor, "Effectiveness of the multidimensional curriculum model in developing higher-order thinking skills in elementary and secondary students," Curric. J., vol. 29, no. 1, pp. 95-115, Jan. 2018, doi: 10.1080/09585176.2017. 1318771 